\title{
Destinasyon Rekabetçiliğinde İmaj, Değer ve Kalite: Şehirlerarası Bir Karşılaştırma
} (Araştırma Makalesi)

\author{
Image, Value and Quality in Destination Competitivity: Cross-City \\ Comparison
}

Doi: 10.29023/alanyaakademik.684501

\author{
Aykut ŞiMŞEK \\ Dr. Öğr. Üyesi, Kastamonu Üniversitesi, Gastronomi ve Mutfak Sanatları Bölümü \\ asimsek@kastamonu.edu.tr \\ Orcid No: 0000-0002-3317-2330
}

\section{Çetin AKKUŞ}

Dr. Ögrr. Üyesi, Kastamonu Üniversitesi, Gastronomi ve Mutfak Sanatları Bölümü cakkus@kastamonu.edu.tr

Orcid No: 0000-0002-6539-726X

Bu makaleye atıfta bulunmak için: Şimşek, A., Akkuş, Ş. (2021). Destinasyon Rekabetçiliğinde Imaj, Değer ve Kalite: Şehirlerarası Bir Karşılaştırma. Alanya Akademik Bakış, 5(1), Sayfa No.111-126.

Anahtar kelimeler:
Kültür,
Kastamonu,
Çankırı,
Destinasyon Imajı,
Algılanan Değer,
Deneyim Kalitesi
Makale Geliş Tarihi:
04.02.2020
Kabul Tarihi:
02.12.2020

Keywords:

Culture,

Kastamonu,

Çankırı,

Destination Image,

Perceived Value,

Experience Quality

\section{ÖZET}

Ulusal kültüre ait değerler, normlar ve kurallar gibi unsurlar turistlerin davranışlarını, beklentilerini, algılarını önemli ölçüde etkilemektedir. Özellikle ortak turistik ve kültürel değerler taşıyan komşu destinasyonlarda turistlerin zihinlerinde oluşan destinasyon imaj, yaşadıklar deneyimin kalitesi ve alglladıkları değer destinasyon rekabetçiliğinde önemli bir avantaj sağlamaktadır. Bu nedenle araştırmada iki komşu destinasyon olan Kastamonu ve Çankır illerinin ziyaretçilerin gözünden destinasyon imajl, algllanan değer ve deneyim kalitesi düzeylerini tespit etmek ve bu iki şehrin birbirine üstün oldukları boyutları incelemek amaçlanmıştır. Araştırma kapsamında Kastamonu ve Çankırı şehir merkezlerinde toplam 701 kişiye yönelik anket uygulanmiştır. Yapılan analizler sonucunda Kastamonu şehrinin destinasyon imajı, algılanan değeri ve deneyim kalitesinin Çankırı şehrinden anlamlı ve pozitif farklılı̆̆a sahip olduğu tespit edilmiştir. 
scope of the research, a questionnaire was applied to 701 people in Kastamonu and Çankirl city centers. As a result of the analyzes, it was determined that the destination image, perceived value and experience quality of Kastamonu city has a significant and positive difference from Çankırl city.

\section{GİRIŞ}

Turizm destinasyonu turistik ürünün temel bir parçasıdır ve her destinasyon onu diğerlerinden ayıran bir imaja sahiptir. Olumlu bir destinasyon imajı yaratmak ve onu yönetmek turizm destinasyonları için planlama, tanıtım ve politika belirleme noktasında temel bir unsurdur (Lee ve Lee, 2009). Algılanan değer ise müşterilerin hizmet veya üründen hissettikleri faydanın derecesi olarak tanımlanabilir (Yu ve Fang, 2009) ve deneyim kalitesi ile yakından ilgilidir. Çünkü deneyim kalitesi müşterilerin katılmış oldukları tüketim faaliyetlerinin sonucunda zihinlerinde oluşturdukları kararları ifade etmektedir. Dolayısıyla müşterilerin seyahat deneyimlerini algılama kalitesi algılanan değer seviyelerini de o derece etkileyecektir. Ayrıca deneyim bir pazarlama stratejisi olarak da değerlendirilmektedir. Bu kapsamda da işletmelerin müşteri deneyimini yaşatabilmeleri (Günay, 2008) ve tüketicilerin deneyime duygusal biçimde dahil olmalarından dolayı seçim kararlarını etkilediği için deneyimsel pazarlama önem taşımaktadır (Keskin ve Dedeoğlu, 2020). Deneyimsel pazarlama müşteri deneyimlerine odaklanarak (Schmitt, 1999) satın alma öncesi ile sonrasını kapsayan bütüncül bir deneyimdir (Berry, Carbone ve Haeckel, 2002).

Destinasyon imajına, algılanan değere ve deneyim kalitesine yönelik farklılıklar farklı turist grupları arasındaki kültürel değerler ile yakından ilgilidir. Çünkü kültürel değerler bir toplumun duygularının, düşüncelerinin, tutum ve davranışlarının ana kaynağıdır. Dolayısıyla kültürel değerler insan düşüncesinin, duygularının ve davranışlarının merkezinde yer alır (Lee ve Lee, 2009). Ayrıca kültürel özellikler bir ürünün gerçek çekiciliği için hayati bir öneme sahiptir. Çünkü turizm, farklı geçmişlerden gelen insanlar tarafından tüketilen bir hizmettir (Sabiote Ortiz vd., 2016). Günümüzde de her hafta sonu ve tatil günlerinde binlerce insan birkaç saatliğine de olsa tarihi veya mimari çekiciliği olan yerleri ziyaret etmek için seyahat etmektedirler. Aynı davranışı büyük kıyı kesimlerine ve şehirlere giden turistler de gösterebilmektedir (Royo Vela, 2009). Bu kapsamda Türkiye sadece kıyısı olan büyük şehirlere değil bütün topraklarına yayılmış doğal güzellikleri, kültürel değerleri olan tarihi destinasyonlarıyla önemli bir mirasa sahiptir. Ancak bu tür destinasyonlarda daha iyi bir turizm ve pazarlama yönetimi için ilgili yerler ile alakalı bilgi toplamak oldukça önemlidir.

Son yıllarda turizmin kültürel yönlerine büyük ilgi duyulmaktadır. Kültürün çeşitli şekil ve boyutlarda turizm planlaması, gelişimi, yönetimi ve pazarlanması üzerinde önemli etkisi vardır. Ancak ulusal kültürün turizm davranışları üzerindeki etkilerinin incelenmesi ihmal edilmiştir. Ulusal kültüre ait değerler, normlar ve kurallar gibi unsurlar turistlerin davranışlarını, beklentilerini, algılarını önemli ölçüde etkilemektedir (Reisinge ve Turner, 2012). Ayrıca turistlerin zihinlerinde oluşan destinasyon imajı, yaşadıkları deneyimin kalitesi ve algıladıkları değer destinasyon seçiminde ve tekrar ziyaretlerinde etkili olmaktadır. Özellikle ortak turistik ve kültürel değerler taşıyan komşu destinasyonlarda bu parametrelerde sağlanacak gelişmelerin destinasyon rekabetçiliğinde önemli bir avantaj sağlayacağı açıktır. $\mathrm{Bu}$ nedenle araştırmada iki komşu destinasyon olan Kastamonu ve Çankırı illerinin 
ziyaretçilerin gözünden destinasyon imajı, algılanan değer ve deneyim kalitesi düzeylerini tespit etmek ve bu iki şehrin birbirine üstün oldukları boyutları incelemek amaçlanmıştır.

\section{DESTINASYON İMAJI, ALGILANAN DEĞER, DENEYIMM KALITESİ}

Destinasyon imajı, turistlerin bir destinasyona yönelik genel izlenimleri şeklinde tanımlanabilir. Yani bir ziyaretçinin belirli bir yer ile ilgili düşüncelerinin, fikirlerinin ve izlenimlerinin toplamı olduğunu söylemek mümkündür (Pike ve Page, 2014; Xu ve Ye, 2018; Beerli ve Martin, 2004). Destinasyon imaj1, bir destinasyonun sahip olduğu somut özellikler kadar önemlidir (Pike, Kotsi ve Tossan, 2018) ve turistlerin bir destinasyonu seçerken karar vermesinde, seyahatini değerlendirmesinde ve gelecekteki turizm davranışlarını belirlemesinde oldukça etkilidir. Çünkü seyahat deneyimleri sonucu oluşan olumlu bir imaj, destinasyonun olumlu bir şekilde değerlendirilmesini sağlayacaktır (Chi ve Qu, 2008).

Olumlu bir destinasyon imajı bir ülkenin turizm, iş, yatırım firsatları ve uluslararası ilişkilerindeki sahip olduğu imajını etkilemekte ve geliştirmektedir (Martinez ve Alvarez, 2010). Söz konusu imaj, yazılı tanıtımlar (seyahat broşürleri, posterler), başkalarının görüşleri (aile, arkadaş, seyahat acenteleri) ve medya (gazete, TV, kitap, dergi, film) gibi birçok kaynaktan sağlanmaktadır (Echtner ve Ritchie, 2003). Doğal kaynaklar, turistik eğlence ve rekreasyon, genel alt yapı özellikleri, turizm altyap1sı, kültür, tarih ve sanat, politik ve ekonomik faktörler, doğal çevre, sosyal çevre ve destinasyon atmosferi de bu imajı oluşturan boyutlardır (Beerli ve Martin, 2004).

Turizm alanında destinasyon imajına yönelik birçok çalışma (Zhang vd., 2014; Beerli ve Martin, 2004; Trauer ve Ryan, 2005; Molina, Gómez ve Martín-Consuegra 2010; Lojo, Li ve Xu, 2020; Lee ve Xue, 2020) gerçekleştirilse de kültürlerarası karşılaştırmaların az olduğunu söylemek mümkündür. Bir filmin farklı ülkelerdeki izleyicilerin algıları üzerindeki etkilerini ölçmeyi amaçlayan Hudson, Wang ve Gil (2011), Güney Amerika'nın öne çıktığı bir filmi ABD, Kanada ve İspanya'daki izleyicilere izletmişlerdir. Katılımcıların büyük çoğunluğu filmin çekildiği ülkeyi ziyaret etmek istediklerini belirtmişler ve özellikle de Kanadalı izleyiciler diğer iki ülke izleyicilerine göre daha istekli olduklarını ifade etmişlerdir. Dolayısıyla bir filmin destinasyon imajı ve seyahat kararı üzerinde çok güçlü bir etkiye sahip olduğunu belirtmişlerdir. Mackay ve Fesenmaier (2000) de destinasyon imajının değerlendirilmesi noktasında kültürlerarası oluşabilecek farkları incelemek için bir çalışma yürütmüşlerdir. $\mathrm{Bu}$ kapsamda araştırma örneklemine Tayvanlılar ve Amerikalılar dahil edilmiştir. Sonuç olarak bir destinasyonun imajını değerlendirilirken suyun (ırmak, göl, deniz vb.) Tayvanlıların için en belirgin etken olduğunu ifade etmişlerdir. Elliot ve Papadopoulos (2016) ise bir yere ait imajda alt bileşenlerinin ne kadar ilişkili olduğunu belirlemek için Kanada ile Güney Korelileri kapsayan kültürlerarası bir çalışma yapmışlardır. Turistik ürün değerlendirmesi yapılırken bilişsel ülke imajının en büyük etkiye sahip olduğunu, destinasyon değerlendirmesinde ise duygusal ülke imajının en büyük etken olduğunu belirtmişlerdir.

Algılanan değer dinamik bir değişken olup satın almadan önce, satın alma anında, kullanım sırasında ve sonrasında yaşanan tecrübeyi ifade etmektedir (Sanchez vd, 2004). Para, fayda, kalite ve sosyal psikoloji açısından da algılanan değeri tanımlamak mümkündür. Bishop'a göre (1984) parasal açıdan algılanan değere bakıldığında tüketicilerin bir ürüne ödedikleri fiyat ile ödemek istedikleri en yüksek fiyat arasındaki fark anlaşılmaktadır. Fayda açısından değerlendirildiğinde de tüketicilerin algıladıkları kazançlarını ve kayıplarını genel olarak değerlendirmesidir. Yani tüketicilerin bir ürün alırken neye sahip olduklarını ve neyden 
vazgeçtiklerini düşünmesidir. Kalite ise Zeithaml (1988) tarafindan ödenen fiyat ile ürünün kalitesi arasındaki fark olarak ifade edilmiştir. Sosyal psikoloji açısından ise tüketicilerin sahip oldukları sosyo-demografik özelliklere göre satın aldıkları ürünü değerlendirmesidir (Kuo, Wu ve Deng, 2009).

Algılanan değerin temel düzeyde ana hatlarıyla kavramsallaştırılması Zeithaml (1988) tarafından yapılmıştır. Bu kapsamda araştırmalarında tüketicilerin fiyat, kalite ve değer algıları arasındaki ilişkilere odaklanmış ve algılanan değer ile ilgili dikkat çeken özellikleri belirlemiştir. Sonuç olarak da algılanan kalitenin algılanan değere yol açtığını, bunun da satın alma niyetlerini önemli ölçüde pozitif bir şekilde etkilediğini belirtmiştir (Petrick ve Backman, 2002). Ayrıca belirli bir yere ait yüksek algılanan değer algısı ziyaretçilerin söz konusu yeri tekrar ziyaret etme ihtimalini de arttıracaktır (Quintal ve Polczynski, 2010; Cronin vd., 2000). Bu kapsamda Iniesta-Bonillo, Sánchez-Fernández ve Jiménez-Castillo (2016) ziyaretçilerin bir turistik destinasyona yönelik algılanan değer ve memnuniyetleri arasındaki ilişkileri incelemişlerdir. İspanya (Cullera) ve İtalya'daki (Oristano) turistik destinasyonlarda gerçekleştirilen araştırmada algılanan değerin memnuniyeti olumlu yönde etkilediğini belirtmişlerdir. Benzer şekilde Chi ve arkadaşları (2020) algılanan değer ile memnuniyet ve algılanan kalite arasında olumlu bir ilişki olduğunu ifade etmişlerdir. Sabiote Ortiz ve arkadaşları (2016) da İspanyol ve İngiliz turistlerin herhangi bir otelde konaklama konusunda satın alma karar verme süreçlerinde algılanan değerin oluşmasına yönelik karşılaştırmalı bir çalışma yapmışlardır. Karşılaştırma çevrimiçi (internet) ve çevrimdış1 (seyahat acentesi) olmak üzere iki önemli dağıtım kanalları arasında yapılmıştır. Çalışma sonucunda her iki kültürde de oluşabilecek riskin algılanan değeri doğrudan etkilemediğini, otel kalitesinin dolaylı şekilde etkilediğini belirtmişlerdir.

Deneyim kalitesi, insanların bir geziye veya turistik seyahate bağlı olarak deneyimledikleri faydalar ve sonuçlar olarak tanımlanmaktadır (Cole ve Scott, 2004). Bu kavram aynı zamanda fiziksel çevre, hizmet sağlayıcılar, diğer müşteriler, müşterilerin arkadaşları ve müşterilerin kendilerini içeren tüm deneyimler hakkındaki duygusal yargılardır (Chang ve Horng, 2010) ve tüketimin deneyimlenmiş yönlerinin daha iyi anlaşılmasını sağlar. Yani turistlerin turizm faaliyetlerine katılmasıyla elde ettiği psikolojik sonuçları ifade etmektedir (Cole ve Scott, 2004). Söz konusu bu deneyimler hem turistlerin memnuniyet düzeylerini hem de destinasyonların hizmet kalitesini ifade etmektedir. Literatürde, turizm alanında deneyim kalitesi ile ilgili çok sayıda akademik çalışma (Fernandes ve Cruz, 2016; Zins, 2002; Jiricka vd., 2010; Cole ve Illum, 2006; Suhartanto vd., 2020; Moon ve Han, 2019) yapıllmışken kültürlerarası çalışmalara rastlanılmamıştır.

\section{TURIZM DESTINASYONU OLARAK KASTAMONU VE ÇANKIRI ÍLLERI}

Bilinen tarihi Hitit İmparatorluğu ile başlayan Kastamonu'da tarihsel süreç içerisinde Frigler, Lidyalılar, Kimmerler, Persler, Pontuslular, Romalılar ve Bizanslılar hakimiyet sürmüştür. Danişmentliler zamanında da Türklerin eline geçerek Türk beylikleri ve Osmanlı İmparatorluğu'nun idaresi altında olmuştur (www.kastamonu.ktb.gov.tr, 2020). Dolayısıyla söz konusu kültürlere ait çok sayıda esere ev sahipliği yaptığını söylemek mümkündür. Kastamonu, kültürel ve doğal değerler açısından zengin bir yerleşim yeridir (Gürbüz, 2005). Karadeniz Bölgesi'ndeki Zonguldak, Gümüşhane, Tokat, Trabzon ve Sinop illeriyle birlikte mağara varlığı bakımından oldukça zengindir (Aylar, Zeybek ve Dinçer, 2019). Doğa turizmi, 
kırsal turizm (Ertuna vd. 2012), kış turizmi, inanç turizmi ve kıyı turizmi (Kastamonu Rehberi, 2018) bakımından da önemli bir potansiyele sahiptir. Kanyon, şelale, yayla, mağara gibi çok sayıdaki doğa güzellikleriyle birlikte kirletilmemiş, nispeten bozulmamış ve el değmemiş alanlara ev sahipliği yapmaktadır (Zengin, Koç ve Ulama, 2019). Ayrıca binlerce yıllık kültür birikimi, coğrafi çeşitlilik yöre yemek kültürüne de yansıyarak zengin bir mutfak kültürü ortaya çıkarmıştır (Kastamonu Rehberi, 2018). Dolayısıyla Kastamonu'nun gastronomi turizmi açısından da önemli bir potansiyele sahip olduğunu söylemek mümkündür.

Çankırı, Hititler döneminden itibaren sırasıyla Romalılar, Selçuklular, Danişmentliler, Candaroğulları ve Osmanlı tarafından yerleşim yeri olarak kullanılmıştır (Tuna, 2010). Tarihi, kültürel ve doğal değerleriyle Çankırı, Türkiye'nin turizm potansiyeli açısından önemli destinasyonlarından biridir ve kent imajının oluşumunda dini ve tarihi yapılar önemli yer tutmaktadır (Öztürk, 2020). Yayla turizmi için elverişli yaylaları, sportif olta balıkçılığı, inanç turizmi, sahip olduğu önemli kaplıcaları sağlık turizmi açısından önem taşımaktadır (Kara, 2006). Özellikle Ilgaz Dağı dağ ve kış turizmi amacıyla kullanılan önemli bir turizm ve rekreasyon alanıdır (Çankırı İl Turizm Envanteri, 2005). Ayrıca, dağ bisikleti, kampçılık, dağ yürüyüşü, izcilik, dağcılık, karavan turizmi gibi etkinliklere uygun olup yılın 12 ayında turizm hareketlerini bünyesinde barındırmaktadır (www.çankiri.ktb.gov.tr, 2020). Ilgaz denildiğinde akla hem Kastamonu hem de Çankırı illeri gelmektedir ve Kültür ve Turizm Koruma ve Gelişim Bölge'lerinde iki şehir de ifade edilmektedir (Akkuş, 2019).

\section{YÖNTEM}

\subsection{Araştırmanın Amacı}

Bir turistik destinasyonun tercih edilmesinde ziyaretçilerde o destinasyona ilişkin zihninde oluşturduğu imaj çok önemlidir. Bununla birlikte tercih sonrası ziyaretçilerin destinasyonda yaşadığı deneyimin kalitesi ve buna atfettiği değer de destinasyonu tercihte öne çıkan diğer değişkenler olarak karşımıza çıkmaktadır. Özellikle ortak turistik ve kültürel değerler taşıyan komşu destinasyonlarda bu parametrelerde sağlanacak gelişmelerin destinasyon rekabetçiliğinde önemli bir avantaj sağlayacağı açıktır. Bu nedenle araştırmada iki komşu destinasyon olan Kastamonu ve Çankırı illerinin ziyaretçilerin gözünden destinasyon imajı, algılanan değer ve deneyim kalitesi düzeylerini tespit etmek ve bu iki şehrin birbirine üstün oldukları boyutları incelemek amaçlanmıştır.

\subsection{Hipotezler}

Araştırma kapsamında üç hipotez geliştirilmiştir:

$\mathrm{H}_{1}$ : Kastamonu ve Çankırı şehirleri arasında destinasyon imajı açısından farklılık vardır.

$\mathrm{H}_{2}$ : Kastamonu ve Çankırı şehirleri arasında algılanan değer açısından farklılık vardır.

$\mathrm{H}_{3}$ : Kastamonu ve Çankırı şehirleri arasında deneyim kalitesi açısından farklılık vardır.

\subsection{Araştırmanın Kapsamı ve Sınırlılıkları}

Araştırmanın kapsamını Kastamonu ve Çankırı il merkezindeki turistik noktalar oluşturmaktadır. Ayrıca araştırma Kastamonu ili için Mart-Haziran 2018, Çankırı ili için ise Temmuz-Eylül 2018 tarihleri arasında bu bölgeleri ziyaret eden yerli turistler ile sınırlandırılmıştır. 


\section{4. Örnekleme Süreci}

Araştırmanın evrenini söz konusu noktaları belirlenen tarihlerde ziyaret eden 18 yaş ve üzeri kültür turistleri oluşturmaktadır. Evrenin ilgilenilen özellikler bakımından homojen olması sebebiyle tesadüfi olmayan örnekleme yöntemlerinden kolayda örnekleme yöntemi tercih edilmiştir. Çalışmanın \%95 güven aralığında 0.05 önem seviyesinde toplam 384 kişiye yapılması uygun görülmüştür (Altunışık vd, 2012: 137). Hatalı ve eksik anketlerin çıkarılması ile birlikte Kastamonu'dan 379 ve Çankırı'dan ise 322 olmak üzere toplam 701 kişiye ait veri incelemeye alınmıştır.

\section{5. Ön Çalışma}

Kesin anket formu oluşturulmadan önce araştırma örneklemini temsil edecek iki gruptan her bir gruptan 20 olmak üzere toplam 40 kişiye ulaşılmış ve bir pilot çalışma yapılmıştır. Çalışmada katılımcıların ankette yer alan ifadelere ilişkin görüşleri alınmış ve ölçeğin anlaşılırlığı üzerine fikirleri kaydedilmiştir. Bununla birlikte ankete son hali verilmiştir.

\subsection{Araştırmanın Yöntemi}

Araştırmada nicel bir tasarım benimsenmiş ve anket yöntemi kullanılmıştır. Dört bölümden oluşan anketin birinci bölümünde katılımcıların demografik özelliklerini tespite yönelik cinsiyet, yaş, medeni durum gibi bilgileri ve destinasyona geliş sayılarına yer verilmiştir. İkinci bölümde Chen \& Phou (2013) tarafından geliştirilen beş boyut, 16 ifadeden oluşan destinasyon imajı ölçeğinden, üçüncü bölümde Sweeney \& Soutar (2001)'ın geliştirdiği dört boyut, 19 ifadeyi kapsayan algılanan değer ölçeğinden, dördüncü kısımda ise Otto \& Ritchie (2006)'nin dört boyut ve 23 ifadeden oluşan deneyim kalitesi ölçeğinden faydalanılmıştır. Birinci bölüm dışındaki tüm ifadeler 5'li likert ölçeği (5= Kesinlikle katılıyorum; 1= Kesinlikle katılmıyorum) ile derecelendirilmiştir. Anket formları gönüllülük esasına dayalı olarak yüz yüze gerçekleştirilmiştir. Elde edilen verilerin değerlendirilmesinde açıklayıcı faktör analizi ve bağımsız $T$ testinden yararlanılmıştır.

\section{BULGULAR}

\subsection{Demografik Özellikler}

Katılımcıların demografik özelliklerine ilişkin bulgular Tablo 1'de verilmiştir. Buna göre Kastamonu'dan 379 Çankırı'dan ise 322 katılımcıya ulaşılmış olup kadın ve erkek ziyaretçilerin eşit katılım gösterdikleri görülmüştür. Katılımcıların \%45'i evli olup \%55'i ise bekârdır. Yaş aralıkları incelendiğinde cevaplayıcıların \%80'inin 18-45 yaş aralığından oluştuğu ve destinasyonların genç ziyaretçi kitlesinin önemli bir çoğunluğu oluşturduğu görülmektedir. Her eğitim seviyesinden dengeli bir katılımın görüldüğü incelemede en yüksek katılım oranının lise mezunu bireylerde (\%29.7) olduğu tespit edilmiştir. Öğrenci (\%29.8), özel sektör (\%18.3) ve kamu çalışanları (\%12.1)'dan oluşan yoğun katılımcıların oluşturduğu meslekleri ev hanımları ve emekli gibi aktif çalışmada bulunmayan katılımcılar takip etmiştir. 
Tablo 1. Katılımcıların Demografik Özelliklerine İlişkin Bulgular

\begin{tabular}{|c|c|c|c|c|c|}
\hline & $f$ & $\%$ & & $f$ & $\%$ \\
\hline Cinsiyet & & & Ĕgitim Durumu & & \\
\hline Kadın & 356 & 50.0 & İlköğretim & 100 & 14.1 \\
\hline Erkek & 355 & 50.0 & Lise & 211 & 29.7 \\
\hline Medeni Durum & & & Ön lisans & 179 & 25.2 \\
\hline Evli & 320 & 45.0 & Lisans & 166 & 23.3 \\
\hline Bekar & 391 & 55.0 & Lisansüstü & 55 & 7.7 \\
\hline Yaş & & & Meslek & & \\
\hline $18-24$ & 238 & 33.5 & Özel Sektör & 130 & 18.3 \\
\hline $25-35$ & 207 & 29.1 & Kamu Çalışanı & 86 & 12.1 \\
\hline $36-45$ & 118 & 16.6 & Öğrenci & 212 & 29.8 \\
\hline $46-55$ & 65 & 9.1 & İşçi & 45 & 6.3 \\
\hline $56-65$ & 54 & 7.6 & Esnaf & 35 & 4.9 \\
\hline $65>$ & 29 & 4.1 & Emekli & 48 & 6.8 \\
\hline Gelir & & & Ev Hanımı & 82 & 11.5 \\
\hline $0-1499$ & 272 & 38.3 & Serbest Meslek & 32 & 4.5 \\
\hline $1500-2999$ & 211 & 29.7 & Diğer & 41 & 5.7 \\
\hline $3000-4999$ & 144 & 20.3 & Şehre Geliş & & \\
\hline $5000>$ & 84 & 11.7 & İlk Kez & 278 & 39.1 \\
\hline Ziyaret Edilen Şehir & & & 1-3 Defa & 150 & 21.1 \\
\hline Kastamonu & 379 & 53.3 & 3-5 Defa & 81 & 11.4 \\
\hline Çankırı & 332 & 46.7 & $5>$ & 180 & 25.4 \\
\hline
\end{tabular}

Şehre kaçıncı gelişleri olduğu sorulan ziyaretçilerin yaklaşık \%40 ilk kez şehre geldiğini belirtmiştir. Şehir bazlı incelendiğinde Kastamonu örnekleminin \%48'i şehre ilk kez geldiğini ifade ederken Çankırı'yı ilk kez ziyaret edenlerin oranı \%31'de kalmıştır. Buna karşın beş ve üzeri ziyaret sayısında Kastamonu \%14.2'de kalırken Çankırı için bu oran \%40’tır. Bu durum iki şehrin ziyaret sıklığında birbirinden istatistiki olarak anlamlı bir farklılığa sahip olduğunu göstermektedir ( $\mathrm{p}=0.000)$. Buna göre Kastamonu'ya daha çok yeni turistlerin ilgi gösterdiği Çankırı'nın ise daha çok sadık ziyaretçisi olduğu söylenebilir.

\subsection{Araştırma Ölçeklerine Yönelik Faktör Analizi}

Araştırmada yararlanılan destinayon imajı, algılanan değer ve deneyim kalitesi ölçeklerine ilişkin tüm örneklemi kapsayacak şekilde açıklayıcı faktör analizi yapılmıştır. Analizlerde açıklayıcı model olarak temel bileşenler analizi ve varimax döndürme seçenekleri kullanılmıştır. Ölçeklerin her birinde ilişki katsayıları incelendiğinde 0,30 değerinin altında yer alan destinasyon imajı ölçeğindeki bir, algılanan değer ölçeğinden beş ve deneyim kalitesi ölçeğinden ise iki ifade çıkarılmıştır. Ortaya çıkan yeni yapı ile ilgili istatistikler Tablo 2'de verilmiştir. 
Tablo 2. Destinasyon İmajı, Algılanan Değer ve Deneyim Kalitesi Faktör ve Değişkenleri

\begin{tabular}{|c|c|c|c|c|c|}
\hline Destinasyon İmajı & Ort. & $\begin{array}{l}\text { Fakt. } \\
\text { Yükü }\end{array}$ & $\begin{array}{c}\text { Öz } \\
\text { Değer }\end{array}$ & $\begin{array}{l}\text { Açıl. } \\
\text { Vary. }\end{array}$ & $\begin{array}{l}\text { Cron. } \\
\text { Alpha }\end{array}$ \\
\hline Faktör 1:Destinasyon Markast & 3.16 & & 2.616 & 17.441 & 0.812 \\
\hline İnsanlar dürüst ve güvenilirler. & 3.20 & 0.825 & & & \\
\hline İnsanlar turistlere yardım etmeye istekliler. & 3.10 & 0.781 & & & \\
\hline $\begin{array}{l}\text { Burada kişisel olarak kendimi güvende } \\
\text { hissediyorum. }\end{array}$ & 3.40 & 0.729 & & & \\
\hline Harcadığım paranın karşılı̆̆ını alıyorum. & 2.98 & 0.425 & & & \\
\hline Faktör 2:Atmosfer & 3.47 & & 2.534 & 16.893 & 0.827 \\
\hline Buras1 dinlendirici bir yer. & 3.54 & 0.897 & & & \\
\hline Burası dinlenmek için iyi bir yer. & 3.52 & 0.880 & & & \\
\hline Burası barışçı1 bir yer. & 3.38 & 0.430 & & & \\
\hline Faktör 3:Kültürel Çevre & 3.00 & & 2.134 & 14.226 & 0.786 \\
\hline $\begin{array}{l}\text { Şehir sıra dışı yaşam şekilleri ve geleneklere } \\
\text { sahip. }\end{array}$ & 2.98 & 0.769 & & & \\
\hline Bu şehirde birçok kültürel faaliyet yapılıyor. & 2.90 & 0.745 & & & \\
\hline Bu şehir birçok kültürel çekiciliğe sahip. & 3.14 & 0.736 & & & \\
\hline Faktör 4:Doğa & 3.19 & & 1.837 & 12.246 & 0.657 \\
\hline Şehirde güzel göller var. & 2.94 & 0.770 & & & \\
\hline Şehirde doğal parklar var & 3.13 & 0.704 & & & \\
\hline Şehirde güzel dağlar var. & 3.54 & 0.636 & & & \\
\hline Faktör 5:Ĕ̈lence & 2.42 & & 1.648 & 10.989 & 0.622 \\
\hline Şehirde iyi bir gece hayat1 var. & 2.27 & 0.840 & & & \\
\hline Şehirde iyi alışveriş imkânı var. & 2.57 & 0.688 & & & \\
\hline
\end{tabular}

AV: 71.795 KMO: 0.890 Bartlett Testi. $\mathrm{p}<0.000$

\begin{tabular}{|c|c|c|c|c|c|}
\hline \multicolumn{6}{|l|}{ Algllanan Değer } \\
\hline Faktör 1:Duygu & 3.07 & & 3.261 & 23.290 & 0.905 \\
\hline Burası beni rahat hissettiren bir yer. & 3.16 & 0.794 & & & \\
\hline Burası bana kendimi iyi hissettiriyor. & 3.20 & 0.789 & & & \\
\hline Burası yararlanmak isteyeceğim bir yer. & 2.98 & 0.714 & & & \\
\hline Burada bulunmaktan haz duyuyorum. & 3.02 & 0.693 & & & \\
\hline Burası tadı çıkarılabilecek bir yer. & 3.01 & 0.606 & & & \\
\hline Faktör 2: Fiyat & 2.98 & & 3.246 & 23.182 & 0.904 \\
\hline Fiyatına göre iyi ürünler mevcut & 2.91 & 0.820 & & & \\
\hline Şehir genel olarak ekonomik denilebilir. & 3.05 & 0.820 & & & \\
\hline Şehrin fiyat düzeyleri makul. & 3.02 & 0.812 & & & \\
\hline Ziyaretim harcadığım paraya değer. & 2.95 & 0.772 & & & \\
\hline Faktör 3:Kalite & 2.68 & & 2.573 & 18.381 & 0.849 \\
\hline Şehir kabul edilebilir bir kalite standardına sahip & 2.70 & 0.822 & & & \\
\hline Burası iyi yapılandırılmış bir şehir. & 2.59 & 0.811 & & & \\
\hline Șehir tutarlı bir kaliteye sahip & 2.78 & 0.725 & & & \\
\hline Faktör 4:Sosyal & 2.96 & & 1.716 & 12.260 & 0.793 \\
\hline $\begin{array}{l}\text { Burası sosyal olarak kabul edilmeme imkân } \\
\text { sağladı. }\end{array}$ & 2.98 & 0.815 & & & \\
\hline Burası alg1 düzeyimi geliştirmemi sağladı. & 2.95 & 0.780 & & & \\
\hline \multicolumn{6}{|l|}{ AV: 77.114 KMO: 0.932 Bartlett Testi. $p<0.000$} \\
\hline Deneyim Kalitesi & & & & & \\
\hline
\end{tabular}




\begin{tabular}{|c|c|c|c|c|c|}
\hline Faktör 1: $\dot{I}_{c ̧}$ Huzur & 3.24 & & 4.675 & 22.261 & 0.906 \\
\hline Burası fiziksel olarak rahat hissetmemi sağlıyor. & 3.26 & 0.769 & & & \\
\hline $\begin{array}{l}\text { Gizliliğimin garanti altında olduğunu } \\
\text { hissediyorum. }\end{array}$ & 3.24 & 0.763 & & & \\
\hline $\begin{array}{l}\text { Burada kişisel güvenliğimin sağlandığını } \\
\text { hissediyorum. }\end{array}$ & 3.27 & 0.754 & & & \\
\hline Burada rahatlamış hissediyorum. & 3.27 & 0.744 & & & \\
\hline $\begin{array}{l}\text { Burada eşyalarımın güvende olduğunu } \\
\text { düşünüyorum. }\end{array}$ & 3.38 & 0.742 & & & \\
\hline $\begin{array}{l}\text { Buradaki yaşantıya dahil olduğumu } \\
\text { hissediyorum. }\end{array}$ & 3.20 & 0.674 & & & \\
\hline $\begin{array}{l}\text { Buradaki yaşantının bir parçası olduğumu } \\
\text { hissediyorum. }\end{array}$ & 3.08 & 0.589 & & & \\
\hline Faktör 2:İlgi & 3.24 & & 3.323 & 15.824 & 0.853 \\
\hline $\begin{array}{l}\text { Burada insanlarla iş birliği içinde olduğumu } \\
\text { hissediyorum. }\end{array}$ & 3.15 & 0.761 & & & \\
\hline Burada ciddiye alındığımı hissediyorum. & 3.27 & 0.75 & & & \\
\hline Burada önemsendiğimi hissediyorum. & 3.20 & 0.742 & & & \\
\hline Öğrenmiş ve bilgilendirilmiş hissediyorum. & 3.26 & 0.734 & & & \\
\hline $\begin{array}{l}\text { Burada yaptığım şeyler üzerinde kontrol sahibi } \\
\text { olduğumu hissediyorum. }\end{array}$ & 3.33 & 0.526 & & & \\
\hline Faktör 3:Haz & 2.77 & & 3.101 & 14.766 & 0.843 \\
\hline Burada unutulmaz şeyler yaptım. & 2.87 & 0.812 & & & \\
\hline Burada heyecan verici şeyler yaptım. & 2.80 & 0.805 & & & \\
\hline $\begin{array}{l}\text { Burada yaptıklarım hayatımda bir defa } \\
\text { yaşayacağım türden bir tecrübeydi. }\end{array}$ & 2.59 & 0.722 & & & \\
\hline Şehirde gerçekten hoşlandığım şeyleri yaptım. & 2.82 & 0.625 & & & \\
\hline $\begin{array}{l}\text { Burada yaşadığım deneyimleri daha sonra } \\
\text { başkalarıyla paylaşırım. }\end{array}$ & 3.26 & 0.457 & & & \\
\hline Faktör 4:Macera & 2.78 & & 2.565 & 12.214 & 0.803 \\
\hline Bir şekilde hayata meydan okuduğumu hissettim. & 2.83 & 0.837 & & & \\
\hline Hayal gücümün harekete geçtiğini hissettim. & 2.72 & 0.711 & & & \\
\hline $\begin{array}{l}\text { Burada yaşadığım yerden kaçış duygusunu } \\
\text { hissettim. }\end{array}$ & 2.83 & 0.692 & & & \\
\hline Bir macera yaşadığımı hissettim. & 2.76 & 0.673 & & & \\
\hline
\end{tabular}

Destinasyon imajı ölçeği incelendiğinde faktör analizi sonucu beş boyutlu bir yapı elde edilmiştir. Bunlar Faktör 1: Destinasyon markası, Faktör 2: Atmosfer, Faktör 3:Kültürel çevre, Faktör 4: Doğa ve Faktör 5: Eğlence şeklinde oluşmuştur. Oluşan bu yeni yapının varyansı açıklama oranı \%71.795 olarak ölçülmüştür. Toplam varyans içerisinde açıklama oranı ile öne çıkan boyut \%17.441 ile destinasyon markası boyutunda olduğu görülmüştür. Ölçeğin genel Cronbach Alpha değeri 0.890'dır. Alt boyutlar açısından incelendiğinde ise destinasyon markası boyutu 0.812, atmosfer boyutu 0.827 , Kültürel çevre boyutu 0.786, Doğa boyutu 0.657 ve eğlence boyutu için 0.622 olarak ölçülmüştür.

Faktör analizi sonrası algılanan değer ölçeği incelendiğinde dört boyutlu bir yapı ortaya çıkmıştır. Buna göre Faktör 1: Duygu, Faktör 2: Fiyat, Faktör 3: Kalite ve Faktör 4: Sosyal olarak tanımlanmıştır. Ölçeğin varyansı açıklama oranı \% 77.114 olarak ölçülmüştür. Ölçeğin genel Cronbach Alpha değeri 0.937 olarak ölçülmüştür. Alt boyutlarda ise duygu boyutu 
0.905 , fiyat boyutu 0.904 , kalite boyutu 0.849 , ve sosyal boyutu ise 0.793 olarak bulunmuştur.

Deneyim kalitesi ölçeğine yapılan faktör analizi sonucunda ise dört boyut elde edilmiştir. Ölçeğin açıklanan varyans oranı ise 65.066 olarak ölçülmüştür. Ölçeğin genel Cronbach Alpha değeri 0.938 'dir. Alt boyutlar açısından bakıldığında ise Faktör 1: İç huzur için 0.906, Faktör 2: İlgi için 0.853, Faktör 3: Haz için 0.843 ve Faktör 4: Macera için 0.803 olduğu görülmüştür. Ölçeklere ilişkin elde edilen güvenilirlik değerlerinin ve açıklama gücünün sosyal bilimler açısından oldukça güvenilir aralıklarda olduğu söylenebilir (Hair vd. 2010: 92).

\subsection{Araştırma Hipotezlerinin Test Edilmesi}

Araştırma kapsamında geliştirilen hipotezleri test etmek amacıyla bağımsız örneklem $\mathrm{t}$ testi uygulanmıştır. Analize karar verirken öncelikle örneklemin normal dağılım gösterip göstermediği incelenmiş ve bunun sonucunda, hem grup sayıları açısında hem de test değerleri açısından normallik varsayımlarını gerçekleştirdiği görülmüştür. Test sonucunda Kastamonu ve Çankırı'ya yönelik destinasyon imajını oluşturan alt boyutların ortalamalarının birbirinden istatistik olarak anlamlı bir farklılık gösterdiği görülmüştür. Analize ilişkin bulgular Tablo 3 'te verilmiştir.

Tablo 3. Destinasyon İmajının Farklılığına Yönelik Bağımsız T Testi Sonuçları

\begin{tabular}{|c|c|c|c|c|c|c|}
\hline & Şehir & $\mathbf{N}$ & $\mathbf{X}$ & Std. sapma & $\mathbf{t}$ & $\mathbf{p}$ \\
\hline \multirow[t]{2}{*}{ Destinasyon Markası } & Kastamonu & 379 & 3.30 & 0.92247 & 3.794 & $0.000 * *$ \\
\hline & Çankırı & 322 & 3.01 & 1.09453 & & \\
\hline \multirow[t]{2}{*}{ Atmosfer } & Kastamonu & 379 & 3.60 & 1.01152 & 3.373 & $0.001 * *$ \\
\hline & Çankırı & 322 & 3.33 & 1.14704 & & \\
\hline \multirow[t]{2}{*}{ Kültürel Çevre } & Kastamonu & 379 & 3.19 & 0.95009 & 5.156 & $0.000 * *$ \\
\hline & Çankırı & 322 & 2.79 & 1.13371 & & \\
\hline \multirow[t]{2}{*}{ Doğa } & Kastamonu & 379 & 3.35 & 0.91569 & 4.278 & $0.000 * *$ \\
\hline & Çankırı & 322 & 3.02 & 1.12989 & & \\
\hline \multirow[t]{2}{*}{ Ĕglence } & Kastamonu & 379 & 2.52 & 1.10174 & 2.305 & $0.021 *$ \\
\hline & Çankırı & 322 & 2.32 & 1.20656 & & \\
\hline
\end{tabular}

Ortalamalar incelendiğinde tüm boyutlarda Kastamonu için yapılan değerlendirmelerin daha yüksek ortalamalara sahip olduğu tespit edilmiştir. Kastamonu'nun en yüksek ortalamaya sahip olduğu boyut 3.60 ile atmosfer olurken her iki şehrin de en düşük ortalamaya sahip olduğu boyut eğlence $(2.52 ; 2.32)$ olmuştur. Bu doğrultuda "Kastamonu ve Çankırı şehirleri arasında destinasyon imajı açısından farklılık vardır" şeklinde kurulan $\mathrm{H}_{1}$ hipotezi kabul edilmiştir.

Kastamonu ve Çankırı'nın destinasyon algılanan değerine ilişkin yapılan farklılık analizi sonuçları Tablo 4'te verilmiştir. 
Tablo 4. Algılanan Değer Farklılığına Yönelik Bağımsız T Testi Sonuçları

\begin{tabular}{|c|c|c|c|c|c|c|}
\hline & Şehir & $\mathbf{N}$ & $\mathbf{X}$ & Std. sapma & $\mathbf{t}$ & $\mathbf{p}$ \\
\hline \multirow[t]{2}{*}{ Duygu } & Kastamonu & 379 & 3.20 & 1.00866 & 3.588 & $0.000 * *$ \\
\hline & Çankırı & 322 & 2.91 & 1.14244 & & \\
\hline \multirow[t]{2}{*}{ Fiyat } & Kastamonu & 379 & 3.07 & 1.05738 & 2.383 & $0.017 *$ \\
\hline & Çankırı & 322 & 2.87 & 1.23370 & & \\
\hline \multirow[t]{2}{*}{ Kalite } & Kastamonu & 379 & 2.81 & 0.94805 & 3.213 & $0.001 * *$ \\
\hline & Çankırı & 322 & 2.54 & 1.27726 & & \\
\hline \multirow[t]{2}{*}{ Sosyal } & Kastamonu & 379 & 3.00 & 1.04780 & 1.017 & 0.310 \\
\hline & Çankırı & 322 & 2.91 & 1.20574 & & \\
\hline
\end{tabular}

Tablo 4 incelendiğinde algılanan değer ölçeğinin alt boyutları olan duygu, fiyat ve kalite boyutlarına ilişkin değerlendirmelerin iki şehir açısından anlamlı bir farklılığa sahip olduğu görülmüştür. Ortalamalar incelendiğinde üç boyut açısından yine Kastamonu şehrinin daha yüksek bir ortalamaya sahip olduğu görülmüştür. Sosyal boyutta ise anlamlı bir farklılığa rastlanmamıştır. Bu sonuçlar 1 şığında "Kastamonu ve Çankırı şehirleri arasında algılanan değer açısından farklılık vardır" şeklinde kurulan $\mathrm{H}_{2}$ hipotezi kısmen kabul edilmiştir. Fakat her ne kadar ortalamalar arası farklılık söz konusu olsa da ortalama değerler incelendiğinde iki şehrin ziyaretçileri de seyahatleri boyunca harcanan paralarının karşılığını yeterince alamadıkları ve tutarlı bir kalite ile buluşmadıklarını beyan ettikleri görülmektedir.

Araştırmada son olarak iki şehrin deneyim kalitesine yönelik ortalamalar incelenmiş ve sonuçlar Tablo 5'te verilmiştir. Analiz sonucuna göre ilgi, haz ve macera boyutlarına ilişkin değerlendirmelerde iki şehir arasında anlamlı bir fark bulunmazken sadece iç huzur boyutunda istatistiki olarak anlamlı bir farklılık görülmüştür $(\mathrm{t}=1.981 ; \mathrm{p}=0.048)$. Ortalamalar incelendiğinde Kastamonu şehrinde ziyaretçilerin Çankırı'ya nazaran kendini daha güvende hissettiği tespit edilmiştir.

Tablo 5. Deneyim Kalitesi Farklılığına Yönelik Bağımsız T Testi Sonuçları

\begin{tabular}{|c|c|c|c|c|c|c|}
\hline & Şehir & $\mathbf{N}$ & $\mathbf{X}$ & Std. sapma & $\mathbf{t}$ & $\mathbf{p}$ \\
\hline İç Huzur & Kastamonu & 379 & 3.31 & 0.95974 & 1.981 & 0.048 \\
\hline \multirow{3}{*}{ İlgi } & Çankırı & 322 & 3.16 & 1.00832 & & \\
\hline & Kastamonu & 379 & 3.26 & 0.89446 & 0.705 & 0.481 \\
\hline & Çankırı & 322 & 3.21 & 1.04628 & & \\
\hline \multirow[t]{2}{*}{ Haz } & Kastamonu & 379 & 2.75 & 1.03560 & -0.623 & 0.534 \\
\hline & Çankırı & 322 & 2.80 & 1.10618 & & \\
\hline \multirow[t]{2}{*}{ Macera } & Kastamonu & 379 & 2.78 & 1.00214 & -0.163 & 0.871 \\
\hline & Çankırı & 322 & 2.79 & 1.09807 & & \\
\hline
\end{tabular}

Elde edilen sonuçlar 1şı̆̆ında "Kastamonu ve Çankırı şehirleri arasında deneyim kalitesi açısından farklılık vardır” ş̧eklinde kurulan $\mathrm{H}_{3}$ hipotezi kısmen kabul edilmiştir. Fakat yine iki şehrin deneyim kalitesi açısından ziyaretçilerin beklentilerini yeterince karşılamadığ görülmüştür. Ortalama değerler incelendiğinde şehirlerin özellikle yeteri kadar macera ortamı sunmadığı, kişinin kendini gerçekleştirmesine imkan vermediği ve yaşanılan deneyimlerin unutulmaz hale gelmediği söylenebilir. 


\section{SONUÇ VE ÖNERILER}

Turizm pazarlamasındaki değişen koşullarla birlikte turizm destinasyonları rekabet etme noktasında çok sayıda zorluklarla karşılaşmaktadır. Dolayısıyla destinasyonlar etkili pazarlama stratejileri geliştirmek için büyük çaba sarf etmektelerdir. Bu kapsamda turistlerin sahip oldukları kültürel farklılıkların tespit edilmesinin turizmin gelişmesinde önemli etkisinin olduğunu söylemek mümkündür. Çünkü turistik ürün ve hizmetler farklı kültürdeki turistler için farklı anlamlar taşıyabilir. Dolayısıyla bu çalışmada iki komşu destinasyon olan Kastamonu ve Çankırı illerinin ziyaretçilerin gözünden destinasyon imajı, algılanan değer ve deneyim kalitesi düzeylerini tespit etmek ve bu iki şehrin birbirine üstün oldukları boyutları incelemek amaçlanmıştır.

Çalışma sonuçlarına göre Kastamonu'ya daha çok yeni turistlerin ilgi gösterdiği Çankırı'nın ise daha çok sadık ziyaretçisi olduğu sonucuna varılmıştır. Destinasyon imajını oluşturan destinasyon markası, atmosfer, kültürel çevre, doğa ve eğlence boyutlarında Kastamonu için yapılan değerlendirmelerin daha yüksek olduğu görülmüştür. Özellikle şehir atmosferi konusunda Kastamonu'nun Çankırı'dan pozitif yönde farklılaştı̆̆ı tespit edilmiştir.

Algılanan değer ölçeğinin alt boyutlarından olan duygu, fiyat ve kalite boyutlarına bakıldığında Kastamonu açısından benzer durumun olduğu tespit edilmiştir. Yani ziyaretçilerin şehirlere ilişsin değer algılamalarında Kastamonu'nun daha yüksek bir ortalamaya sahip olduğu ancak sosyal boyutta Çankırı ile bir farklılığın olmadığı görülmüştür. Fakat her ne kadar ortalamalar arası farklılık söz konusu olsa da ortalama değerler incelendiğinde iki şehrin ziyaretçileri de seyahatleri boyunca harcanan paralarının karşılığını yeterince alamadıkları ve tutarlı bir kalite ile buluşmadıklarını beyan ettikleri görülmektedir. İki şehir deneyim kalitesi açısından değerlendirildiğinde ise ziyaretçilerin beklentilerini yeterince karşılamadığ , şehirlerin özellikle yeteri kadar macera ortamı sunmadığı, kişinin kendini gerçekleşmesine imkan vermediği ve yaşanılan deneyimlerin unutulmaz hale gelmediği söylenebilir.

Araştırma, ortak özellikler gösteren Kastamonu ve Çankırı il merkezindeki turistik noktalarla sınırlandırılması sebebiyle gelecekteki çalışmalarda yine benzer özellik taşıyan destinasyonlar belirlenerek karşılaştırma yapılabilir. Ayrıca turizm alanındaki ulusal ve uluslararası kültürlerarası karşılaştırma çalışmaları incelendiğinde özellikle deneyim kalitesi ile ilgili herhangi bir çalışmaya rastlanılmamıştır. Dolayısıyla bu kapsamda söz konusu durumla ilgili çalışmaların sayısı arttırılabilir. Çalışmada Kastamonu ve Çankırı illeri için turistlerin gözünden destinasyon imajı, algılanan değer ve deneyim kalitesi düzeyleri belirlenmiştir. Sonraki araştırmalarda turistlerin demografik ve seyahat davranışı özelliklerine göre kültürlerarası bir karşılaştırma yapılarak çalışma sonuçları pekiştirilebilir.

\section{KAYNAKÇA}

AKKUŞ, G. (2019). Ilgaz dağında kış turizm talebi ve gelişimi. Çankırı Karatekin Üniversitesi İktisadi ve İdari Bilimler Fakültesi Dergisi, 9(1), 1-27.

ALTUNIŞIK, R., ÇOŞKUN, R., BAYRAKTAROĞLU, S. VE YILDIRIM, E. (2012). Sosyal Bilimlerde Araştırma Yöntemleri SPSS Uygulamalı. Sakarya: Sakarya Yayıncılık.

AYLAR, F., ZEYBEK, H. İ. VE DİNÇER, H. (2019). Medil (Köklü) Mağarası (AzdavayKastamonu) ve turizm açısından önemi. Eastern Geographical Review, 24(1), 15-38. 
BEERLI, A., \& MARTÍN, J. D. (2004). Tourists' characteristics and the perceived image of tourist destinations: a quantitative analysis - a case study of Lanzarote, Spain. Tourism management, 25(5), 623-636.

BEERLI, A., \& MARTÍN, J. D. (2004). Factors influencing destination image. Annals of tourism research, 31(3), 657-681.

BERRY, L. L., CARBONE, L. P. \& HAECKEL, S. H. (2002). Managing the total customer experience. MIT Sloan management review, 43(3), 85-89.

CHANG, T. Y., \& HORNG, S. C. (2010). Conceptualizing and measuring experience quality: the customer's perspective. The Service industries journal, 30(14), 2401-2419.

CHEN C-F., PHOU S. (2013), A closer look at destination: Image, personality, relationship and loyalty, Tourism Management, 36(2013), 269-278.

CHI, X., LEE, S. K., AHN, Y. J., \& KİATKAWSIN, K. (2020). Tourist-perceived quality and loyalty intentions towards rural tourism in China. Sustainability, 12(9), 3614.

COLE, S. T. ve ILLUM, S. F. (2006). Examining The Mediating Role of Festival Visitors' Satisfaction in The Relationship Between Service Quality and Behavioral İntentions. Journal of Vacation Marketing, 12(2): 160-173.

COLE, S. T., \& SCOTT, D. (2004). Examining the mediating role of experience quality in a model of tourist experiences. Journal of Travel \& Tourism Marketing, 16(1), 79-90.

CRONIN, J. J., BRADY, M. K. ve HULT, G. T. M. (2000). Assessing The Effects of Quality, Value and Customer Satisfaction on Consumer Behavioral Intentions in Service Environments. Journal of Retailing, 76(2): 193-218.

ÇANKIRI İL TURİZM ENVANTERİ. (2005). Çankırı: Çankırı Valiliği İl Kültür ve Turizm Müdürlüğü.

ELLIOT, S., \& PAPADOPOULOS, N. (2016). Of products and tourism destinations: An integrative, cross-national study of place image. Journal of Business Research, 69(3), 1157-1165.

ERTUNA, B., GÜNEY, S., GÜVEN, Ö. VE AYDEMİR, N. (2012). Yerel halkın kırsal turizm gelişimine katılma isteğini etkileyen unsurlar: Kastamonu örneği. International Journal of Social and Economic Sciences, 2(2), 59-66.

FERNANDES, T., \& CRUZ, M. (2016). Dimensions and outcomes of experience quality in tourism: The case of Port wine cellars. Journal of Retailing and Consumer Services, 31, 371-379.

GÜNAY, N. G. (2008). Deneyimsel pazarlama: süpermarketler nasıl deneyim yaratabilirler? İşletmecilik Konferansı Bildiri Kitapçığı, 3-6 Eylül, 181-192.

GÜRBÜZ, A. (2005). Kastamonu'ya gelen yerli turist profilini belirlemeye yönelik bir araştırma. Ticaret ve Turizm Eğitim Fakültesi Dergisi, 2, 75-92.

HAIR, J.F., BLACK, W.C., BABIN, B.J. VE ANDERSON, R.E. (2010) Multivariate Data Analysis. (7th Edition). New York: Pearson. 
https://cankiri.ktb.gov.tr/TR-70695/yildiztepe-turizm-merkezi.html, 27.11.2020.

https://kastamonu.ktb.gov.tr/TR-63806/tarihce.html, 26.11.2020.

HUDSON, S., WANG, Y., \& GILL, S. M. (2011). The influence of a film on destination image and the desire to travel: a cross-cultural comparison. International journal of tourism research, 13(2), 177-190.

INIESTA-BONILlO, M. A., SÁNCHEZ-FERNÁNDEZ, R., \& JiMÉNEZ-CASTILLLO, D. (2016). Sustainability, value, and satisfaction: Model testing and cross-validation in tourist destinations. Journal of Business Research, 69(11), 5002-5007.

JIRICKA, A., SALAK, B., EDER, R., ARNBERGER, A., \& PRÖBSTL, U. (2010). Energetic tourism: exploring the experience quality of renewable energies as a new sustainable tourism market. WIT Transactions on Ecology and the Environment, 139(4), 55-68.

KARA, M. (2006). Çankırı'nın turizm potansiyeli ve Çankırı Yâranının turizme kazandırılması. Çankırı Araştırmaları Dergisi, 1(1), 271-281.

KASTAMONU REHBERİ (2018). Kastamonu: Kastamonu Valiliği, İl Kültür ve Turizm Müdürlüğü.

KESKİN, B. \& DEDEOĞLU, B. B. (2020). Günlük tur deneyiminde cinsiyetin rolü: Kapadokya örneği. Journal of Tourism Research Institute, 1(1), 59-70.

KUO, Y. F., WU, C. M., \& DENG, W. J. (2009). The relationships among service quality, perceived value, customer satisfaction, and post-purchase intention in mobile valueadded services. Computers in human behavior, 25(4), 887-896.

LEE, G., \& LEE, C. K. (2009). Cross-cultural comparison of the image of Guam perceived by Korean and Japanese leisure travelers: Importance-performance analysis. Tourism Management, 30(6), 922-931.

LEE, S. W., \& XUE, K. (2020). A model of destination loyalty: Integrating destination image and sustainable tourism. Asia Pacific Journal of Tourism Research, 25(4), 393-408.

LOJO, A., LI, M. \& XU, H. (2020) Online tourism destination image: components, information sources, and incongruence, Journal of Travel \& Tourism Marketing, 37:4, 495-509, DOI: 10.1080/10548408.2020.1785370.

MARTÍNEZ, S. C., \& ALVAREZ, M. D. (2010). Country versus destination image in a developing country. Journal of Travel \& Tourism Marketing, 27(7), 748-764.

MOLINA, A., GÓMEZ, M., \& MARTÍN-CONSUEGRA, D. (2010). Tourism marketing information and destination image management. African Journal of Business Management, 4(5), 722-728.

MOON, H., \& HAN, H. (2019). Tourist experience quality and loyalty to an island destination: The moderating impact of destination image. Journal of Travel \& Tourism Marketing, 36(1), 43-59.

OTTO, J. E. VE RITCHIE, J. R. B. (1996). The Service Experience in Tourism. Tourism Management, 17(3): 165-174. 
ÖZTÜRK, Y. (2020). Yerel halkın bölge turizmine bakış açılarının ve farkındalıklarının belirlenmesi üzerine Çankırı'da bir araştırma. Seyahat ve Otel İşletmeciliği Dergisi, 17(3), 427-443.

PETRICK, J. F. \& BACKMAN. (2002). An Examination of The Construct of Perceived Value for The Prediction of Golf Travelers' Intentions to Revisit. Journal of Travel Research, 41(1): 38-45.

PIKE, S., \& PAGE, S. J. (2014). Destination Marketing Organizations and destination marketing: A narrative analysis of the literature. Tourism management, 41, 202-227.

PIKE, S., KOTSI, F., \& TOSSAN, V. (2018). Stopover destination image: A comparison of salient attributes elicited from French and Australian travellers. Journal of Destination Marketing \& Management, 9, 160-165.

QUINTAL, V. A. \& POLCZYNSKI, A. (2010). Factors Influencing Tourists' Revisit Intentions. Asia Pacific Journal of Marketing and Logistics, 22 (4): 554-578.

REISINGER, Y., \& TURNER, L. (2012). Cross-cultural behaviour in tourism. Routledge.

ROYO-VELA, M. (2009). Rural-cultural excursion conceptualization: A local tourism marketing management model based on tourist destination image measurement. Tourism Management, 30(3), 419-428.

SABIOTE-ORTIZ, C. M., FRÍAS-JAMILENA, D. M., \& CASTAÑEDA-GARCÍA, J. A. (2016). Overall perceived value of a tourism service delivered via different media: A cross-cultural perspective. Journal of Travel Research, 55(1), 34-51.

SANCHEZ, J., CALlARİSA, L., RODRİGUEZ, R. M., \& MOLINER, M. A. (2006). Perceived value of the purchase of a tourism product. Tourism management, 27(3), 394-409.

SCHMITT, B. (1999). Experiential marketing. Journal of marketing management, 15(1-3), 53-67.

SUHARTANTO, D., BRIEN, A., PRIMIANA, I., WİBISONO, N., \& TRIYUNI, N. N. (2020). Tourist loyalty in creative tourism: the role of experience quality, value, satisfaction, and motivation. Current Issues in Tourism, 23(7), 867-879.

SWEENEY, J. C. VE SOUTAR, G. N. (2001). Consumer Perceived Value: The Development of a Multiple Item Scale. Journal of Retailing, 77(2): 203-220.

TUNA, F. (2010). Çankırı'nın coğrafi özelliklerinin şehirsel gelişim potansiyeli yönünden değerlendirilmesi. Marmara Coğrafya Dergisi, 21, 219-239.

XU, H., \& YE, T. (2018). Dynamic destination image formation and change under the effect of various agents: The case of Lijiang,'The Capital of Yanyu'. Journal of Destination Marketing \& Management, 7, 131-139.

ZENGIN, B., KOÇ, D. E. \& ULAMA, Ş. (2019). Kastamonu ilinin doğa turizmi potansiyelinin alternatif turizm kapsamında değerlendirilmesi. Safran Kültür ve Turizm Araştırmaları Dergisi, 2(2), 251-274. 
ZHANG, H., FU, X., CAI, L. A., \& LU, L. (2014). Destination image and tourist loyalty: A meta-analysis. Tourism management, 40, 213-223.

ZINS, A. H. (2002). Consumption emotions, experience quality and satisfaction: a structural analysis for complainers versus non-complainers. Journal of Travel \& Tourism Marketing, 12(2-3), 3-18. 